\title{
Administration of Telecommunication Company Staff Potential in Ukraine
}

\author{
Iryna Kovshova, Nataliia Dubovyk, Tetiana Zubko
}

\begin{abstract}
The goal of the article is to develop theoretical and methodological guideline and practical recommendations for administration of staff potential by telecommunication companies based on marketing management in the modern conditions. The methodological basis of the research are fundamentals of the modern socio-economic theory, management and marketing grounded on the system-synergistic approach to staff potential administration in domestic telecommunication companies and international corporations in Ukraine. Within the framework of this approach, general scientific and specific methods of cognition have been used, in particular: analysis and synthesis, scientific abstraction, deduction and induction, dialectical analysis, statistical analysis, economic and mathematical modeling. The scientific novelty of the research lies in the development of system-synergetic paradigm of marketing management in telecommunication companies, which provides optimal harmonization of goals of companies with various benefits of interested parties to create a social effect. Conclusions. Implementation of marketing management by domestic telecommunication companies and international corporations in Ukraine is favourable for creating reputation of a reliable supplier of products and services to consumers, popularization of an employer brand, maximum satisfaction of consumer requirements, formation of balanced management system with coordination of actions according to different dynamic cycles for simultaneous achievement of economic and organizational effectiveness and a social effect.
\end{abstract}

Key words: marketing management, telecommunication company, staff potential, TC company, social effect, employer brand, economic and organizational effectiveness, managerial staff, staff potential administration.

\section{INTRODUCTION}

Transformation of the modern social, economic and organizational processes determines the development of new approach to managing domestic telecommunication (TC) companies and representative offices of international corporations in Ukraine based on the joint participation paradigm. The above mentioned paradigm is grounded on the possibility of temporary use of existing resources by a company or investors, intellectual potential of employees and

Revised Manuscript Received on June 10, 2020.

* Correspondence Author

Kovshova I. O., professor at Department of marketing and business management, National University «Kyiv-Mohyla academy», Ukraine.E-mail: iryna_kovshova@ukr.net

Dubovyk N. A.*, associate Professor, Department of Documentation and Information, State University of Telecommunications (Kyiv, Ukraine) E-mail: ndubovyk@bel.ua

Zubko T. L., associate Professor at Department of Economics and Finance, Kyiv National University of Trade and Economics, Ukraine. E-mail: zubkotl@gmail.com

(C) The Authors. Published by Blue Eyes Intelligence Engineering and Sciences Publication (BEIESP). This is an open access article under the CC BY-NC-ND license (http://creativecommons.org/licenses/by-nc-nd/4.0/) donor funds for various interested parties. At the same time, the scientific and technological progress promotes implementation of joint participation paradigm by forming modern innovation technologies, which stimulate the demand for domestic telecommunication equipment, products or services and make it possible to attract investors and partners. Evaluation of marketing environment conditions in TC companies of Ukraine combined with deep analysis of social, economic, organizational, scientific and technological factors helps the managerial staff of a company to expand geographical boundaries of providing services to consumers and to promote a company brand as a reliable supplier and a loyal employer. However, this strategy requires application of innovative approaches to company staff potential administration based on marketing management taking into account the trends in social environment development.

Thereafter, a feature of administration of TC company staff potential in Ukraine based on marketing management is implementation of innovation methodology combining a large number of components into the system in order to set up effective communication channels between hierarchical levels within a company to form its positive brand and promote its products or services. The mentioned innovative approach to TC company staff potential administration provides a combination of creativity of new managerial methods and economic and organizational effectiveness at different hierarchical levels (separate units, definite employees, managerial staff).

\section{ANALYSIS OF RECENT RESEARCH AND PUBLICATIONS}

Theoretical and applied guideline of company administration in different branches based on marketing management were considered in the works of Kotler F., Keller K. [9], Lambin J.-J. [8], Voichak O. [2], Bilovodska O. [1], Kovshova I. [5; 6], Pekar V. [10]. Though there are various theoretical approaches to marketing management, most scholars view it as a process of marketing department administration. The lack of scientifically justified methodology of marketing management in a TC company as a holistic administration system in conditions of steady market dynamics has determined the urgency and relevance of this research. The goal of the article is to develop theoretical and methodological guideline and practical recommendations for staff potential administration by telecommunication companies based on marketing management in the modern conditions. The theoretical and methodological basis of the research are fundamentals of the modern socio-economic theory, management and marketing.

Published By:

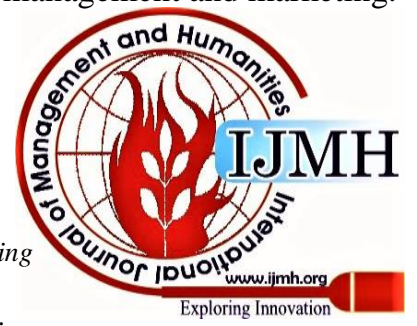


It is grounded on the system-synergistic approach to staff potential administration in domestic telecommunication companies and international corporations in Ukraine. Within the framework of this approach, general scientific and specific methods of cognition have been used, in particular: analysis and synthesis to study the content of marketing management in a company, scientific abstraction to justify specific features of a TC company in Ukraine, deduction and induction to select the main factors of the effect on telecommunication companies, dialectical analysis to carry out theoretical generalizations and establish trends of marketing management development, statistical analysis to study the activities of the Ukrainian telecommunication operators and providers, economic and mathematical modeling to create a TC company staff potential administration model.

\section{PRESENTATION OF BASIC MATERIAL OF THE RESEARCH}

The marketing management concept is grounded on the theory of individual choice coming out of consumer priority principle and requires a complex system of encouraging all potential participants to make a certain contribution into achievement of general welfare [12]. That is, telecommunication companies realize products or provide certain services and in such a way contribute in satisfaction of the needs of consumers and a whole society. The partners' loyalty increases the basic value of produced products or provided services and makes telecommunication sphere more popular. The rise of company's revenue allows managerial staff to pay decent salaries to their employees and provide bonuses to their partners. Motivated managers and employees implement innovations for effective development of a telecommunication company and realize new more successful products and services at the market. Accordingly, marketing management forms a company staff potential administration methodology and functions in certain dynamic cycles varying depending on established goals.

Nowadays, the managerial staff of telecommunication companies must simultaneously achieve economic and organizational effectiveness and a social effect. Implementation of the first component allows the company to maintain an optimal level of profitability and revenues from products or services. Implementation of the second component helps a telecommunication company to achieve a social effect, that is: to create a definite need or to satisfy it, to give a status or modality to telecommunication projects. This duplication requires clarification of existing paradigms in marketing management development during administration of a company's human resources. The main paradigms are summarized and presented in Fig. 1.

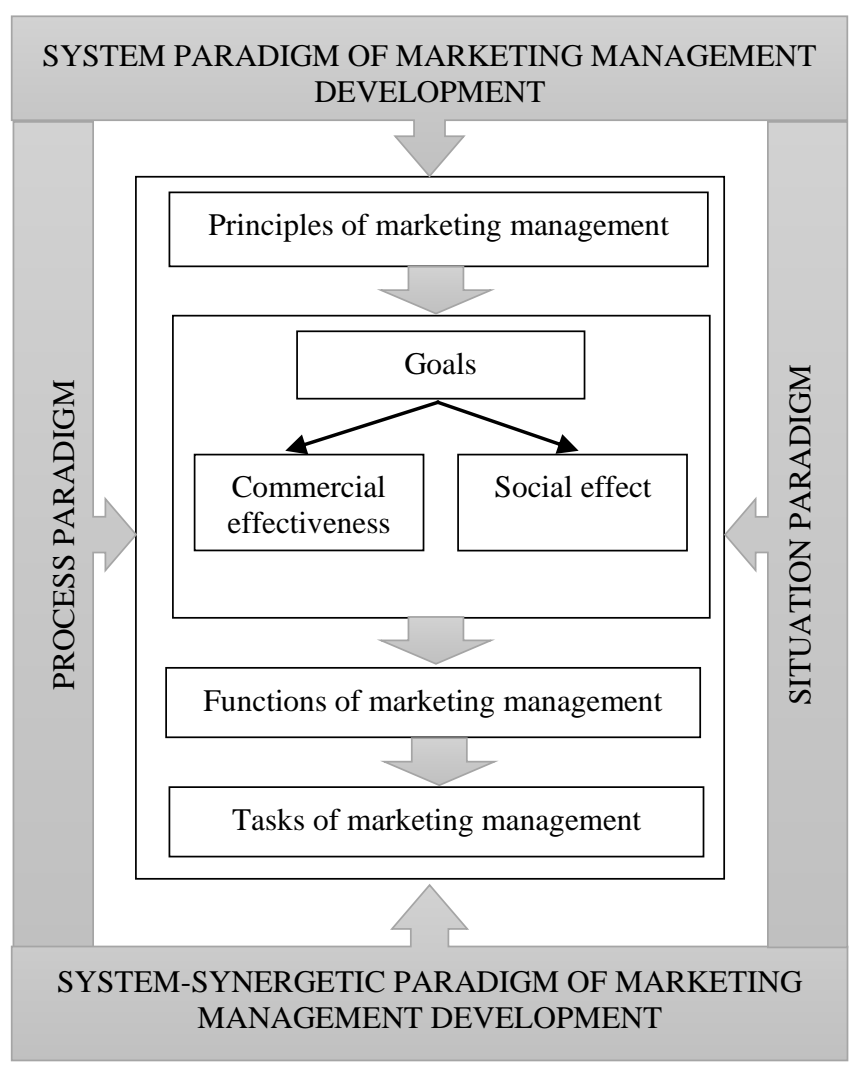

Fig. 1. The main paradigms of marketing management development in TC companies (based on [3])

The system, process and situation paradigms of marketing management development are completed by the system-synergetic one, which is different from the others and provides an optimal combination and harmonization of goals of TC companies having different benefits of interested parties for joint achievement of economic and organizational effectiveness and socio-cultural effect.

In the course of the research the following up-to-date trends were distinguished: companies' finances spent on promotion of telecommunications in Ukraine are increasing, but their effectiveness is falling; in view of globalization of human resources, it is difficult for managerial stuff to keep their employees on site and to find qualified candidates for open vacancies.

It determined creation of a modified system-synergetic paradigm in marketing management of telecommunication companies with the use of the generation theory and the concept of joint participation in projects (Fig. 2).

The system, process and situation paradigms of marketing management development are completed by the system-synergetic one, which is different from the others and provides an optimal combination and harmonization of goals of TC companies having different benefits of interested parties for joint achievement of economic and organizational effectiveness and socio-cultural effect.

In the course of the research the following up-to-date trends were distinguished: companies' finances spent on promotion of telecommunications in Ukraine are increasing, but their effectiveness is falling; in view

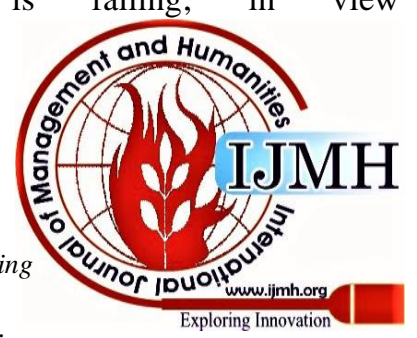




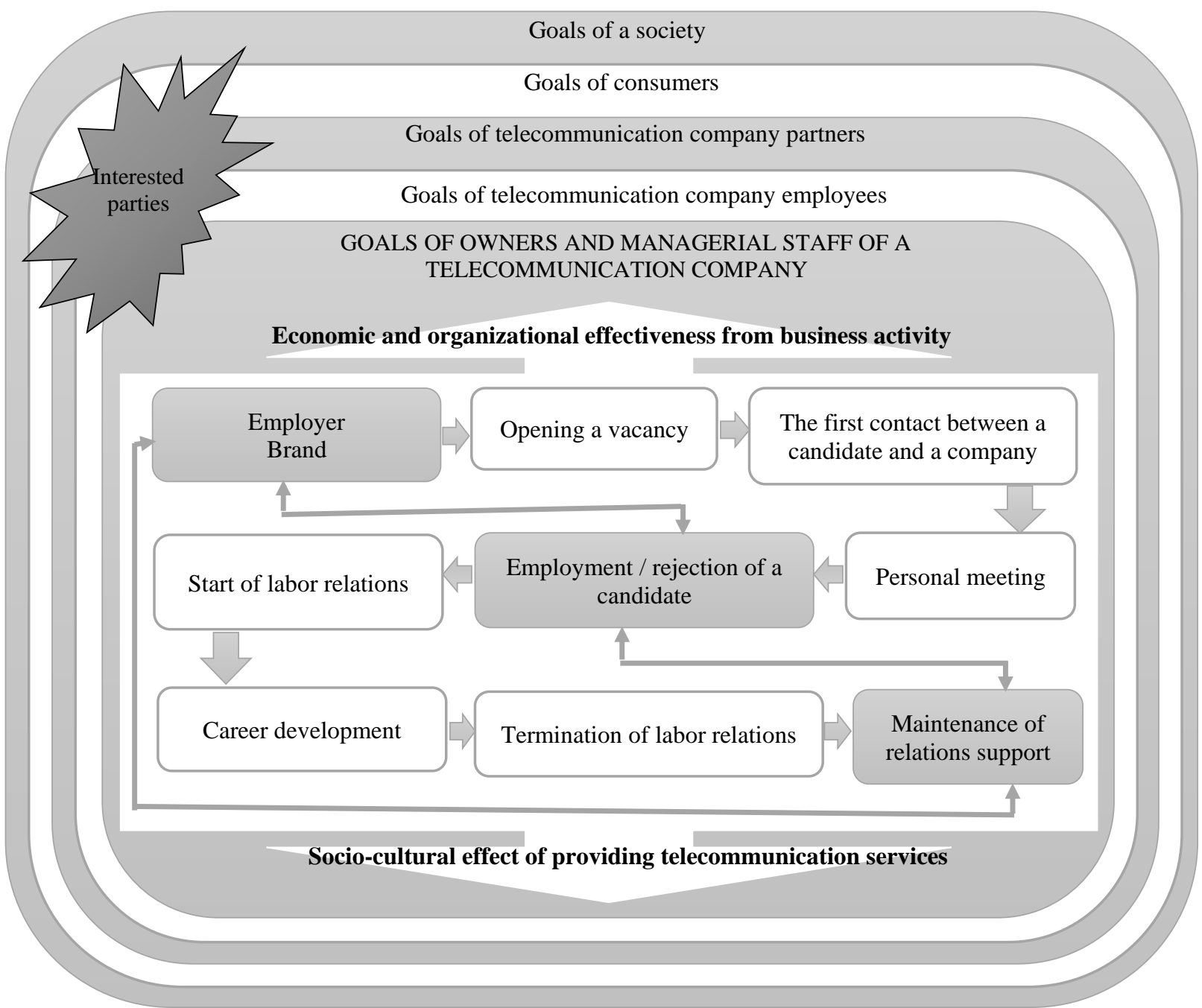

Fig. 2. Levels of marketing management goals harmonization during TC company staff potential administration in Ukraine (based on $[5,6]$ )

of globalization of human resources, it is difficult for managerial stuff to keep their employees on site and to find qualified candidates for open vacancies.

It determined creation of a modified system-synergetic paradigm in marketing management of telecommunication companies with the use of the generation theory and the concept of joint participation in projects (Fig. 2).

The central place in the dynamic cycles system is taken by block "Goals of owners and managerial staff of a telecommunication company", which closely correlate with block "Goals of telecommunication company employees" [5; 6]. According to the generation theory the social aspect of a society development is an integral part of the human history, which effects on the behavioral model and a type of thinking of a modern individual or a particular community [14]. In compliance with the "multi-colored management" theory the thinking paradigm was typified by definite colors [10]. And today you can observe a gradual replacement of the blue collective paradigm by the individual orange one represented by generations " $\mathrm{Y}$ " and "Z". Thus, the managerial staff of a telecommunication company have to focus on the orange administrative culture where decisions are made in specially created groups or projects and formalities of the working process are gradually disappearing.
Grounding on the generation theory and the concept of joint participation in projects, the progress of telecommunication companies in Ukraine directly depends on staff's career development and a marketing management stage. Communication between the managerial staff and employees who are internal clients of a company, has become a certain translator of internal corporate values, which simultaneously retranslate a brand of a telecommunication company to external consumers and partners.

The features of administration of telecommunication company staff potential in Ukraine grounding on marketing management (MM) were studied based on the data collected at twenty-four TC companies (Table 1) [5]. Having used the method of correlation analysis [3; 11], we revealed a significant correlation between the level of implementing marketing management measures by a telecommunication operator or provider and approaches to staff potential administration.

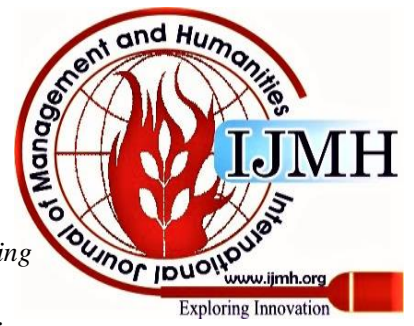




\section{Administration of Telecommunication Company Staff Potential in Ukraine}

Table 1. Database for creating a model of correlation between the levels of implementing marketing management measures by TC companies and approaches to staff potential administration in Ukraine (dated 01.01.2018)

\begin{tabular}{|c|c|c|c|c|c|}
\hline № & TC company name & $\begin{array}{l}\text { Level of implementing MM } \\
\text { measures by a TC company }\end{array}$ & $\begin{array}{c}\text { Rate } \\
(\text { Rmm })\end{array}$ & $\begin{array}{c}\text { Approach to staff potential } \\
\text { administration }\end{array}$ & $\begin{array}{c}\text { Rate } \\
(\text { Omm })\end{array}$ \\
\hline 1 & PRJSC "AO-SVIAZ" & Fragmentary & 1 & Linear and functional & 3 \\
\hline 2 & PRJSC "Belcom" & Global & 3 & Democratic & 10 \\
\hline 3 & PRJSC "VF UKRAINE" & Local & 2 & Regional and divisional & 6 \\
\hline 4 & PJSC "DATAGROUP" & Local & 2 & Conglomerate & 9 \\
\hline 5 & LLC "ZANET" & Global & 3 & Matrix & 7 \\
\hline 6 & PJSC "INTERPIPE NTRP" & Fragmentary & 1 & Linear and functional & 3 \\
\hline 7 & PSC "CABLE TELEVISION SYSTEM" & Local & 2 & Regional and divisional & 6 \\
\hline 8 & KYIVSTAR JSC & Local & 2 & Regional and divisional & 6 \\
\hline 9 & PJSC "PODIL TELEPHONE COMPANY & Global & 3 & Matrix & 7 \\
\hline 10 & PRJSC "POEZ" & Fragmentary & 1 & Linear and functional & 3 \\
\hline 11 & PRJSC "PROMETEY-TELECOM" & Global & 3 & Adaptation & 8 \\
\hline 12 & PSC "PROMTELECOM" & Fragmentary & 1 & Regional and divisional & 6 \\
\hline 13 & PSC "SVEMON-ZAKHID" & Local & 2 & Matrix & 7 \\
\hline 14 & PJSC "CST-INVEST" & Global & 3 & Matrix & 7 \\
\hline 15 & LLC "SINET" & Global & 3 & Segment and divisional & 5 \\
\hline 16 & LLC "SONET" & Global & 3 & Democratic & 10 \\
\hline 17 & PJSC "SUMYKHIMPROM" & Fragmentary & 1 & Product and divisional & 4 \\
\hline 18 & PSC "TELECOM SERVICES" & Local & 2 & Segment and divisional & 5 \\
\hline 19 & PJSC "TELESYSTEMS OF UKRAINE" & Local & 2 & Regional and divisional & 6 \\
\hline 20 & PRJSC "TOP NET" & Global & 3 & Adaptation & 8 \\
\hline 21 & PSC "UKRTELECOM" & Local & 2 & Regional and divisional & 6 \\
\hline 22 & PJSC "FARLEP INVEST" & Local & 2 & Segment and divisional & 5 \\
\hline 23 & PRJSC "KHARKIV ONLINE" & Fragmentary & 1 & Functional & 2 \\
\hline 24 & PRJSC "KHARKIVPROMZVYAZOKBUD" & MM is not realized & 0 & Linear and functional & 3 \\
\hline
\end{tabular}

*Fragmentary - realization of MM in a separate subdivision; local - realization of MM in several subdivisions; global realization of MM in a whole company.

To verify the hypothesis regarding the above mentioned correlation a one-factor model was built based on a linear relations between variables, where $Y_{i}$ means the level of MM measures realization in a TC company, and $x_{i}$ - the approach to staff potential management process administration:

$$
Y_{i}=a_{0}+a_{1} x_{i}+\varepsilon,
$$

where $Y_{i}$ - the level of MM measures realization in a TC company; $x_{i}$ - the approach to staff potential management process administration; $a_{0}, a_{1}$ - parameters that have to be estimated; $\varepsilon$ - unobservable random variable.

The estimated equation of regression of correlation between the levels of implementing marketing management measures by TC companies and approaches to staff potential administration looks as follows:

$$
\hat{Y}=0,313 x_{i}+0,148 \text {. }
$$

Determination coefficient $R^{2}=0,609$ indicates the existence of close relations between variables. F-criterion according to the model made up 34,2. At significance level $\alpha=0,01$ and a freedom degree number $n-m=24-1=23$ and $m=1$ value $F_{\text {tabl }}=7,88$. Whereas $F_{\text {calc }}>F_{\text {tabl }}$, the revealed regression equation is reliable and proposed model of correlation between the levels of implementing marketing management measures by TC companies and approaches to staff potential administration in Ukraine can be implemented on practice.

Significance of correlation coefficient $(R)$ was verified grounding on calculation of Student's $t$-test $[4 ; 7]$ :

$$
t_{\alpha}=\frac{R \sqrt{n-m}}{\sqrt{1-R^{2}}}=\frac{\sqrt{0,609^{2}(24-1)}}{\sqrt{1-0,609}}=4,670817
$$

Using the data of statistical tables at significance level $\alpha=0,10$ and degrees of freedom 23, value $t_{t a b l}=2,500$. Whereas $t>t_{t a b l}$, it proves the hypothesis of correlation coefficient significance. However, to estimate significance of values of pair regression model parameters we have calculated $t$-criterion:

$$
t_{j}=\frac{\left|\hat{a}_{j}\right|}{\sigma_{\hat{a}_{j}}} .
$$

Published By:

Blue Eyes Intelligence Engineering

\& Sciences Publication

(C) Copyright: All rights reserved.

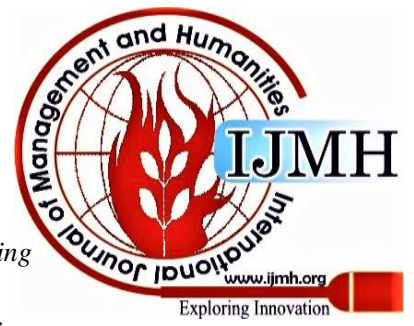


As a result of calculation, we have received: $t_{0}=0,44$, $t_{1}=5$,848. At significance level $\alpha=0,05$ and degrees of freedom $n-m=24-1=23, t_{\text {tabl }}=1,714$. That is parameter $a_{1}$ is statistically significant, as $t_{1}>t_{t a b l}$, but $a_{0}$ is lower, that is why it is necessary to check if there is a degree correlation between the levels of implementing marketing management measures by TC companies and approaches to staff potential administration. The calculation results are the following: $a_{0}=-0,555, a_{1}=0,719$. Respectively, the degree model gained the following look:

$$
Y_{\text {calc }}=\exp (-0,555) X_{1}^{0,719}=0,574 \cdot X_{1}^{0,719} .
$$

On calculating determination coefficients of the two models, it was established that the most accurate one is the first model built by linear dependence. Summarized results of the research are shown on Fig. 3, where the level of implementing marketing management measures by TC companies in Ukraine is marked on the horizontal axis, and approaches to staff potential administration - on the vertical axis. Using the above mentioned variables, you can define an optimal approach to arrangement of staff potential administration process by a telecommunication operator or provider.

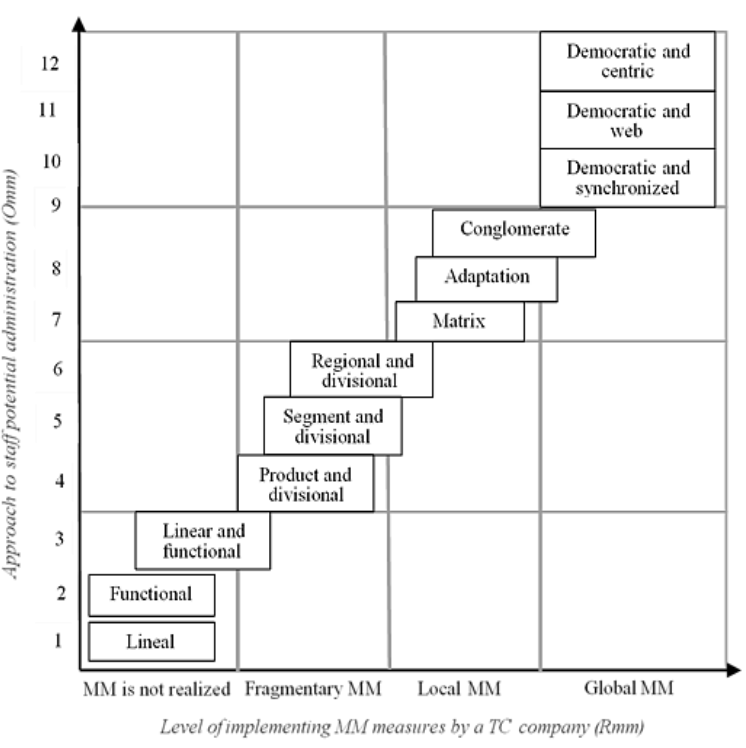

Fig. 3. Correlation between the levels of implementing marketing management measures by TC companies and approaches to staff potential administration in Ukraine (based on [5]).

To avoid interest conflicts between the managerial staff and employees of a TC company, it is necessary to follow the concept of partners' relations. It means that only joint interaction of all participants in dynamic cycles allows to achieve economic and organizational effectiveness from activity of a TC company and receive a social effect.

Respectively, in the course of company staff potential administration managers have to recognize that potential, real and former employees can either improve or worsen reputation of a TC company. To support an employer brand, managers should maintain partnership at all stages of communication: starting from the first meeting with an applicant for an open vacancy up to maintenance of friendly relations on termination of labor relations with this employee.
The most difficult stage is to make a decision on including a candidate in the staff or reject him/her. Regardless of the decision made this stage significantly effects on an employer brand. If a candidate is taken to the position, the process goes on and labor relations start. If a candidate is rejected, managers of a TC company must move to the last stage of the cycle, set up friendly relations with the applicant and maintain them in the future. On termination of labor relations between an employee and a TC company, managers should also maintain relations with him/her. The proposed algorithm of the communication process described above allows managers of TC companies to popularize their brands and involve potential, real and former employees in future activities.

According to the system-synergetic paradigm of marketing management the main goals have specific hierarchy and structure. The economic and organizational goals are closely related to administration, commodity, distribution and price policies of TC companies. The social ones are focused on achieving effect of popularization of telecommunication products and services through establishing by managers friendly partnership with all participants of the dynamic cycles [13].

\section{CONCLUSIONS}

Implementation of marketing management by domestic telecommunication companies and international corporations in Ukraine is favourable for creating reputation of a reliable supplier of products and services to consumers, popularization of an employer brand, maximum satisfaction of consumer requirements, formation of balanced management system with coordination of actions according to different dynamic cycles for simultaneous achievement of economic and organizational effectiveness and a social effect. A feature of administration of TC company staff potential in Ukraine based on marketing management is implementation of innovation methodology combining a large number of components into the system in order to set up effective communication channels between hierarchical levels within a company to form its positive brand and promote its products or services. The mentioned innovative approach to TC company staff potential administration provides a combination of creativity of new managerial methods and economic and organizational effectiveness at different hierarchical levels (separate units, definite employees, managerial staff). The features of administration of telecommunication company staff potential in Ukraine grounding on marketing management were studied based on the data collected at twenty-four TC companies. Having used the method of correlation analysis, we revealed a significant correlation between the level of implementing marketing management measures by a telecommunication operator or provider and approaches to staff potential administration in Ukraine. Using the correlation model variables, you can define an optimal approach to arrangement of staff potential administration process by a telecommunication operator or provider.

Published By: Blue Eyes Intelligence Engineering \& Sciences Publication (C) Copyright: All rights reserved. 
The scientific novelty of the research lies in the development of system-synergetic paradigm of marketing management in telecommunication companies, which provides optimal harmonization of goals of companies with various benefits of interested parties to create a social effect.

\section{REFERENCES}

1. Bilovodska, O.A. (2008). Marketyngovyi menedzhment [Marketing Management], available at: http://westudents.com.ua/glavy/37655-rozdl-1-rozumnnya-marketingov ogo-menedjmentu.html (access date April 25, 2020)

2. Voichak, A.V. (2000). Marketyngovyi menedzhment [Marketing Management]. Kyiv: KNEU, Ukraine, 100 p.

3. Golubkov, Y.P. (2000). Marketingovyye issledovaniya: teoriya, metodologiya i praktika [Marketing research: theory, methodology and practice]. Moscow: Finpress, Russia, $464 \mathrm{p}$.

4. Zdrok, V.V. and Lagotskiy, T.Y. (2010). Ekonometriya [Econometrics]. Kyiv: Znannya, Ukraine, 541 p.

5. Kovshova, I.O. (2018). Marketingovyi menedzhment: teoriia, metodologia, praktika [Marketing Management: Theory, Methodology, Practice], monograph. Herson: FOP Vyshymyrskii, Ukraine, 516 p.

6. Kovshova, I.O. (2017). Orhanizatsiya marketynhovoho menedzhmentu na pidpryyemstvi [Arrangement of marketing management at companies], available at: http://www.economyandsociety.in.ua/journal/11 ukr/41.pdf (access date April 21, 2020)

7. Kuzmenko, I.V. (2014). Ekonomiko-matematychni metody ta modeli (ekonometryka) [Economic and mathematical methods and models (econometrics)]. Sumy: University book, Ukraine, 406 p.

8. Lambin, Jean-Jacques (2007). Menedzhment, oriyentirovannyy na rynok [MARKET-DRIVEN MANAGEMENT Strategic \& Operational Marketing]. St.-Peterburg, Russia, 800 p. (Series "Classics MBA").

9. Kotler, Philip T., Keller Evin L. and Pavlenko, A.F. (2008). Marketyngovyi menedzhment [Marketing Management]. Kyiv: Himdzhest, Ukraine, $720 \mathrm{p}$.

10. Pekar, V. (2019), Riznobarvnyi menedzhment [Multicolored management]. Harkiv: Folio, Ukraine, $191 \mathrm{p}$.

11. Cherchill, G.A. and D.Yakobuchchi (2004), Marketingovyye issledovaniya [Marketing research]. St.-Peterburg: Neva, Russia, 832 p.

12. Arrow, Kenneth J. (2004). Kollektivnyu vybor i individualnye tsennosti [Social Choice and Individual Values]. Moscow: GU BSHE, Russia, $202 \mathrm{p}$.

13. McCarthy, E. Jerome. (1996). Basic Marketing: A Managerial Approach. Homewood, IL: Irwin, 770 p.

14. Howe, N. and Strauss W. (2009). Millennials Rising: The Next Great Generation. New York: Vintage Books, 432 p.

\section{AUTHORS PROFILE}

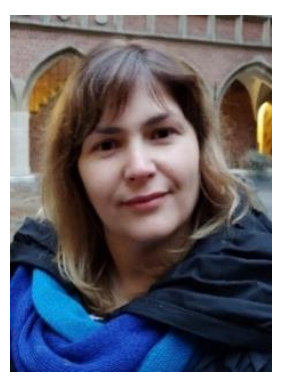

Dr. Iryna Kovshova, is a professor at Department of Marketing and Business Management, National University "Kyiv-Mohyla Academy", Ukraine. Her re- search works are focused on theory and practice of marketing management, be- havioral economics, neuromarketing tech- nologies, methodology of making optimal management solutions with application of economy and mathematical models. The main focus of her scientific researches: Improvement of company efficiency by means of marketing management tools and neuromarketing technologies.

The author's courses of lectures delivered in National University "Kyiv-Mohyla Academy": Marketing management; Management solutions theory; Marketing policy of communications; Change management. The author has more than 65 publications. The most important of them for published for the last two years in science-based editions:

- Kovshova I. Marketing Management: Theory, Methodology, Practice, monograph, Ukraine. 2018. 516 p.

- Kovshova I., Sydorenko O., Zubko T. Prospective trends in neuromarketing tools of the food industry in view of Ukrainian society digitalization. International Journal of Recent Technology and Engineering (IJRTE). 2019. Volume-8. Issue 3C.

- Kovshova I., Dubovyk N., Kuruliuk N. Tendencies of Telecommunication Companies Development in the Conditions of

Ukrainian Society Digitalization. International Journal of Management and Humanities (IJMH).Volume-4 Issue-9, May 2020. P. 124-130.

https://orcid.org/0000-0001-9013-0180

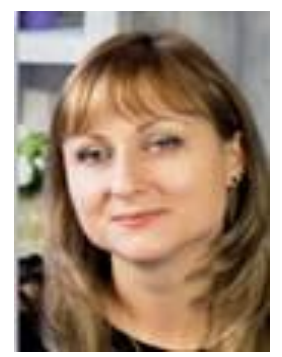

Nataliia Dubovyk, is Candidate of Political Sciences, Associate Professor, Department of Documentation and Information, State University of Telecommunications (Kyiv, Ukraine). Her research works are focused on social technology.

Main areas of research: communication technologies, image communications, public relations technologies, political analysis, political management, communication studies and manipulative technologies in corporate management. The following courses were uniquely designed for the State University of Telecommunications: Imageology, Theory and Practice of Public Relations, Political Science, Ethics of Business Communication and Rhetoric. The author has more than 40 publications. The most important of them were published over the last two years in science-based editions:

- Kovshova I., Dubovyk N., Kuruliuk N. Tendencies of Telecommunication Companies Development in the Conditions of Ukrainian Society Digitalization. International Journal of Management and Humanities (IJMH).Volume-4 Issue-9, May 2020. P. 124-130.

- Dubovyk N.A, Kyryliuk N.A Political science and political technologies: a textbook. Ukraine. 2020. 166 p.

- Kyryliuk N. A., Dubovyk N. A. Special aspects of communication support of entrepreneurship in Ukraine // Challenges and prospects for the de- velopment of social sciences in Ukraine and EU countries: a comparative analysis: Collective monograph. Riga: Izdevniecība «Baltija Publishing», 2019. P.119-131.

Full member of the editorial board of the scientific publication Social and Humanitarian Bulletin: a collection of scientific works of social sciences and humanities - creative workshop "New Course". Kharkiv, Ukraine https://orcid.org/0000-0003-0151-9480

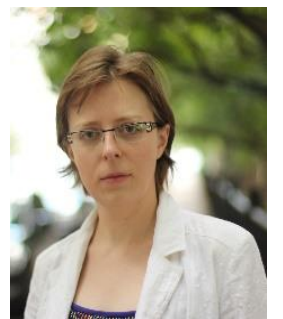

its economic security.

The author's cours of lectures delivered in Kyiv National University of Trade and Economics: Economic security of the enterprise.

The author has more than 50 publications. The most important of them for published for the last two years in science-based editions: Mazaraki A, Boiko M., Okhrimenko A., Melnychenko S., Zubko T. The impact of the national tourism system on the economic growth in Ukraine. Problems and Perspectives in Management, 2019. 17(4), PP. 93-103.

Zubko T., Kovshova I., Sydorenko O. Prospective trends in neuromarketing tools of the food industry in view of Ukrainian society digitalization. International Journal of Recent Technology and Engineering (IJRTE). 2019. Volume-8. Issue 3C.

https://orcid.org/0000-0002-8950-1797
Published By: Blue Eyes Intelligence Engineering \& Sciences Publication (C) Copyright: All rights reserved.

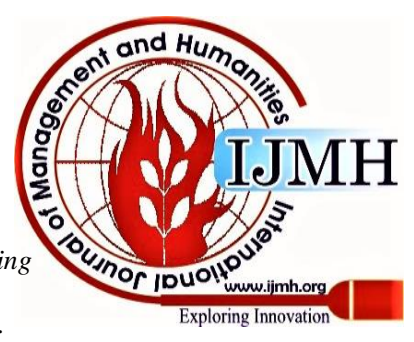

